\title{
Propionibacterium acnes
}

National Cancer Institute

\section{Source}

National Cancer Institute. Propionibacterium acnes. NCI Thesaurus. Code C14378.

A species of relatively slow growing, typically aerotolerant, anaerobic Gram-positive bacteria in the phylum Actinobacteria. 